2018-07-16

\title{
Beyond the management-employee
} dyad: supply chain initiatives in shipping

Tang, Lijun

http://hdl.handle.net/10026.1/11170

10.1111/irj.12210

Industrial Relations Journal

Wiley

All content in PEARL is protected by copyright law. Author manuscripts are made available in accordance with publisher policies. Please cite only the published version using the details provided on the item record or document. In the absence of an open licence (e.g. Creative Commons), permissions for further reuse of content should be sought from the publisher or author. 


\title{
Beyond the management-employee dyad: supply chain initiatives in shipping
}

\author{
Lijun Tang $^{1}$ and Syamantak Bhattacharya ${ }^{2}$
}

\begin{abstract}
This paper examines supply chain health and safety initiatives in the oil shipping industry. In particular, it explores the triangular relationships between ship cargo clients, shipping company management, and seafarers, and reveals the inherent complexities and tensions involved. It shows while managers capitalise on the supply chain pressure to squeeze more effort out of seafarers, seafarers tend to adhere to the corporate line colluding with managers to hide defects and falsify records. Nevertheless, seafarers occasionally use the supply chain leverage to their advantage by tactically exposing ship defects during ship inspections.
\end{abstract}

To be published in Industrial Relations Journal.

\footnotetext{
${ }^{1}$ School of Business, Plymouth University

${ }^{2}$ Warsash School of Maritime Science \& Engineering, Solent University, Southampton
} 


\section{Introduction}

While the management-employee dyad has been the traditional focus of sociology of work, increasingly it is pointed out that this dyadic relationship can no longer capture the full spectrum of working experience due to the changing world of work (Korczynski 2013; Wright and Kaine 2015). First, the rise of service work brings to the fore the role of the customer within the social relations involved in this type of work (Korczynski 2013). Second, as supply chains and global production networks have become indispensable in the global economy, the relationship between suppliers and their business clients is recognised to be an important factor that affects employment practices (Wright and Kaine 2015). Consequently, two types of customers, one being individual customers of service work and the other business clients in supply chains, have generated two bodies of literature that go beyond the managementemployee dyad.

This paper examines the practices of supply chains in the oil shipping industry by drawing on the insights from the literature on customer orientated service work. It not only recognises the worker-customer dyad as an additional dimension in work relations but also pays attention to the role played by customers in monitoring the performance of workers (Fuller and Smith 1991; Gamble 2007; Korczynski et al. 2000). Fuller and Smith (1991) argued that service companies increasingly solicited, collected, and utilised customer feedback to monitor the labour process and manage employees. Therefore employees are under both managerial control and customer control (Bélanger and Edwards 2013; Fuller and Smith 1991). Gamble (2007) pushed the argument further by arguing that the presence of the customer, as a third party, constituted an essential element in the labour process and brought forth a complex triangle of workers, managers and customers. She demonstrated that a range of possible shifting coalitions could 
be formed between the three parties, which manifested 'inherent complexities, ambiguities, contradictions and shifting balances of power' within the triangular relations (Gamble 2007: 21). Thus, research related to customer orientated service work has taken a triangular approach which examines the complex power dynamics among the three parties and raise the question of how and in what context one party can achieve its objectives by drawing on the power of a second to influence the third (Rosenthal 2004).

By contrast, the starting point as well as the core of the extant supply chain literature, is supply chain pressure, with the focus on how this pressure is cascaded from client organisations down to supplier firms and then down to the workers. This approach is inherently linear and one directional. As such, the complex triangular relations, inherent tensions, shifting balances of power, and the associated implications for work and employment relations in supply chains remain to be fully explored. In this context, this paper adopts a triangular approach examining the triangular relations involved in the supply chain of the oil shipping industry. After a review of the literature on supply chain pressure and proposing a triangular approach, this paper will introduce the background of the research and research methods. Then it will discuss the set of relationships involved in the three parties, and draw out the implications in the conclusion.

\section{Supply chain pressure and employment practices}

Supply chains are an essential part of contemporary business activities and involve client firms outsourcing/buying materials, products, or services from suppliers. This paper focuses on buyer-driven chains in which larger buyers/clients at the top have more bargaining power than smaller suppliers. This unequal power distribution produces supply chain pressure, which has implications for work and employment relations in supplier firms. 
Research has shown that such pressure can have both positive and negative impacts depending on how it is exerted by the lead firms. There are cases where lead firms use their power to encourage suppliers to adopt 'high performance' human resource management (HRM) strategies (Marchington and Vincent 2004; Scarbrough 2000; Wright and Kaine 2015). In the UK automotive industry, for instance, a study conducted by Beaumont et al. (1996) showed that customers utilised their market power to facilitate positive employee relations changes in small supplier firms such as an increase in training and employee management communication. Research in the chemical and construction industries (Deakin and Loukiadaki 2009; Marchington and Vincent 2004) as well as in the manufacturing sector (Locke et al. 2013; Distelhorst et al. 2017) found that client firms enforced a range of regulatory initiatives, such as codes of conduct, certification schemes and monitoring programmes, in their supply chains in order to improve working conditions, labour standards and occupational health and safety (OHS) outcomes.

It has been reported that the lead firms tend to take such initiatives largely to protect its reputational risk (Walters and James 2011; Wright and Brown 2013; Wright 2016). Good reputation and a positive brand image are critical factors for business organisations especially those who are customer-facing global brands. It is in their interest to maintain and promote better working conditions and related issues along the supply chain to avoid being associated with 'sweatshops' or such poor practices. In fact, reputational risk is a frequently used leverage by trade unions, non-government organisations, and other civil society groups to put pressure on lead firms to improve labour standards in their supply chains (Wright 2016). Nevertheless, pressure alone does not necessarily guarantee expected outcomes. For such supply chain 
initiatives to work, studies have further revealed that effective monitoring and penalty regimes need to be in place (Walters et al. 2016; Walters and James 2011).

Despite some positive cases, it remains a big challenge to convert supply chain pressure into good employment practices (James et al. 2015) as more often than not such pressure produces negative outcomes. As nearly in every business, the main objective of supply chain management is to reduce costs, with evidence that lead firms often take advantage of their powerful position and transfer costs and risks down to suppliers (Barrientos 2008; 2013; Newsome et al. 2013). With their margins being constantly tightened, the relatively smaller supplier firms lack in capacity and resources to develop and adopt good HRM strategies and find it difficult to recruit and keep quality workers (Carroll et al. 2005). Furthermore, being squeezed from above, they also have to find ways to cut costs. The common way to do this is by opting for 'low-road' HRM strategies (Barrientos 2008; Grimshaw et al. 2005; Hammer and Plugor 2016; Lloyd and James 2008; Newsome 2010; Wright and Kaine 2015), such as using casual and/or agency workers, adopting flexible working hours, and reducing investment in employee development and in improving working conditions. These coping strategies result in work intensification, precarious employment, poor working conditions, adverse OHS outcomes, and even labour abuse (Barrientos 2013; Lever and Milbourne 2017; Mayhew and Quinlan 2006).

While it is established that lead firms have power to exert certain control over their supply chains, the interesting question in the context of this paper is how supply chain pressure influence 'managerial control and workplace regimes' (Thompson and Van den Broek 2010) in supplier firms. Newsome et al.'s research (2013; see also Newsome 2010) on UK retailer 
supply chains showed that in order to meet the demands of their clients, suppliers adopted new technology to monitor labour performance and speed up work processes. Similarly, Pulignano (2002) revealed in her study of supply chains in the Italian automobile industry that the management in supplier firms used supply chain pressure as a mechanism to tighten their control of their labour process. These research findings resonate with the 'customer control' thesis advanced by the literature on customer orientated service work (Bélanger and Edwards 2013; Fuller and Smith 1991; Gamble 2007).

\section{A triangular approach}

The research on customer orientated service work, however, has also advanced a triangular approach, arguing that various alignments of interests can exist within the triangle of workers, managers and customers (Gamble 2007; Rosenthal 2004). While managers and workers are likely to share an interest in influencing customers, in other contexts workers may tacitly use the power of customers to influence managers. In call centres, for example, workers may use quality of service as an excuse to resist the management's pressure on conducting a high volume of calls (Korczynski et al. 2000). Thus, in this triangular approach, each party actively draws on available resources, including the power of other parties, to guard their interests, and such activities and struggles bring to light tensions and contradictions inherent at the workplace.

By contrast, although there is a client-supplier management-worker triangle in supply chains, there is a tendency in the literature to focus on the concept and consequences of 'pressure' which is cascaded down from lead clients to supplier firms and then to workers. Such a concept implies a linear process and power becomes unidirectional which assumes a linear top-down 
pressure. A shortcoming associated with this linear approach is that it overlooks workers' agency and tends to regard them as passive bearers of supply chain pressure and managerial control (Rosenthal 2004; Carswell and De Neve 2013; Selwyn 2011; 2012). This linear approach in supply chain studies is perhaps not surprising, given that supply chain clients are different from individual service customers and that they are powerful organisations enjoying a dominant position in the triangle. This inherent power imbalance, however, does not necessarily mean that workers can only be passive recipients of cascaded pressure.

More recently new debates have brought labour agencies to the foreground in the studies of global supply chains (Carswell and De Neve 2013; Coe and Hess 2013; Selwyn 2011; 2012). Drawing on Wright's (2000) distinction between worker's structural and associational power - while structural power is derived from workers' position in the production process and their ability to disrupt it, associational power is related to collective organisations of workers Selwyn $(2011 ; 2012)$ demonstrates how Brazilian workers in grape farms use both forms of power to advance their interests. Of particular relevance to this paper is that Brazilian grape producers have to follow health and safety standards imposed by global buyers in order to supply to the more lucrative international market. In this context, workers gained structural power in the supply chain and their unions utilised the standards to pressurise employers to improve working conditions in grape farms (Selwyn 2011). In contrast with the focus on topdown pressure, it can be said that this body of literature takes a bottom-up approach to explore workers' agency in supply chains.

The top-down focus on labour control (Newsome et al. 2013; Pulignano 2002) combined with the bottom-up approach to labour agency (Carswell and De Neve 2013; Coe and Hess 2013; 
Selwyn $2011 ; 2012$ ) allude to triangular dynamics. When lead firms take initiatives to improve labour standards and working conditions in their supply chains, arguably the outcomes of these initiatives would be affected by the triangular power relations and dynamics. In this context, this paper proposes and takes a triangular approach to examine supply chain OHS initiatives in the oil shipping industry. This approach is neither top-down nor bottom-up but assumes that each party has direct links with the other two and pays equal attention to the three pairs in the supply chain triangle. This framework is simple, but it will serve to depict a multi-dimensional picture of managerial control and the agency of workers in supply chains, and the picture, in turn, will shed new light on supply chain initiatives.

\section{The shipping industry and oil majors}

The shipping industry has been transformed into one of the most globalised industry by the common practice known as flagging out in which ship owners (who are largely residents in OECD countries) register their ships in the so-called flag of convenience (FOC) countries, such as Panama and Liberia (ILO 2001). On top of reduced taxation liabilities and lower regulatory compliance costs, flagging out allowed ship owners to employ seafarers of any nationality, which gave rise to a global seafarer labour market. In order to cut crew costs, unsurprisingly, ship managers on behalf of ship-owners crew ships with seafarers from low-cost labour supply regions of the globe, such as South East Asia, South Asia, and Eastern Europe. These seafarers are commonly recruited through local crew agencies with short-term contracts lasting for between six and 12 months, and as such precarious agency employment is the hallmark of the global seafarer labour market (ILO 2001). 
Due to its globalised nature, the shipping industry is governed by an elaborately structured national and international regulatory regime. International conventions regulating maritime safety and environment and labour standards are formulated and adopted at global forums such as the International Maritime Organisation (IMO) and the International Labour Organisation (ILO) through multilateral deliberations involving individual states and industry stakeholders. These conventions are then ratified by flags states and enforced by both flag states (the country where the ship is registered) and regional Port State Control (PSC) (the coastal countries where the ship calls). State enforcement mechanisms, however, have weaknesses. Many flag states have neither the resources nor the will (because they compete with each other for tonnage) to enforce regulations strictly. Port states also suffer from resource limitations and can only target a small proportion of visiting ships for inspection, and furthermore, the standards of PSC across the globe are not consistent due to cultural and economic differences (Sampson and Bloor 2007).

In oil shipping, Oil Majors, a collective name for big oil companies, such as Shell, Texaco and Exxon, act as a private regulatory enforcement actor in addition to the State actors. These companies dominate the entire oil supply chain from exploration and production of crude oil to refining, as well as to distribution of the refined petroleum products and are major charterers/ clients of the oil tankers. As there are only a few of them worldwide, they hold significant market power over their transportation suppliers. As a response to increasing public awareness of marine pollution, oil majors set up the Oil Company International Marine Forum (OCIMF) to provide maritime governing bodies with expertise and knowledge in making regulations and guidelines for safe tanker operations. In 1993 OCIMF launched the Ship Inspection Report Programme (SIRE), a safety initiative specifically designed to address concerns about substandard shipping in the tanker sector. The programme involves tanker vetting using a uniform 
inspection protocol by accredited SIRE inspectors. Such vetting is conducted only on a voluntary basis and on invitation from ship managers. The purpose of invitation is to get their ships approved by Oil Majors, typically for a period of 12 months, so that these ships would be fit for carrying oil majors' cargo with an enhanced hire value. The result of an oil major inspection is shared with other commercial organisations involved in oil shipping, such as oil tanker charterers, oil terminal operators and oil traders through the SIRE database.

Due to its coordinated nature, SIRE inspection is more rigorous and more thorough than other forms of inspection and thus more challenging for ship operators. It has been reported (Howell and Bhattacharya 2016) that tanker operators consider oil major inspections more stringent and challenging than the state-based inspection systems. As a result, in the tanker sector in practice, the efforts and allocation of resources for the passing of the state-based inspections are subsumed within the more demanding oil major inspections. In this context, we will not bring the State to the forefront of this discussion especially since the core focus of this paper is on the triangular relationships.

\section{Research Method}

This research used two case studies involving tanker operating companies with the oil majors as their regular clients. Both companies were located in Europe and each operated between 10 and 15 tankers. While one ran relatively larger tankers on worldwide oil trade, the other specialised in transporting petroleum products within Europe. Both companies enjoyed good reputations and had been engaged in the oil transportation business for several years. Their shore-based management office employed around 30 personnel of whom around 10 were 
involved with ship operations and in liaising with Oil Majors. Around five days were spent in each office collecting data from the company managers using semi-structured interviews.

Subsequent to the onshore fieldwork, research voyages were undertaken with two tankers of each organisation. The first two voyages were on ships of the first company sailing in the Persian Gulf and North America while the two remaining voyages on the ships of the second company were undertaken in the European waters. Nearly 50 days were spent on these four ships during which period a total of 67 seafarers were interviewed and non-participant observation was conducted. On each ship, there were four senior officers, the captain, the chief officer, who was the captain's deputy and in charge of the cargo and the ship's stability, the chief engineer, who was in charge of the ship's machinery and, the second engineer, who was responsible for the day-to-day operation of the machineries. The rest were junior officers who were largely in charge of keeping watches and ratings who worked in supporting roles.

The seafarers on board the four ships were of different nationalities. On the two ships of the first company, while senior officers were from Eastern European countries, the rest of the crew were from the Far East. All of them were in temporary employment. On the two ships of the second company, senior officers were from West European countries who were employed permanently, but junior officers and ratings were from Eastern European countries and the Far East who were employed on short-term contracts. The interviews were digitally recorded and later transcribed. These along with the observations, which were noted in a diary, were all systematically coded and analysed.

\section{Cascading down oil majors' pressure}


From the perspective of tanker shipping companies, passing oil majors' inspection was 'the unwritten motto' as failing to do so, could lead to long-term commercial damage. Largely due to the data sharing arrangement of SIRE even if the shipping company did not directly conduct business with the oil major conducting the inspection, the outcome of such inspection would be accessible to all organisations signing up to SIRE. As one ship manager explained:

They [Oil majors] are omnipresent. Even when we are not chartered by them we may go to their terminals or get sub-chartered to them or they could be the sellers or the receivers of the cargo. Everyone asks for [oil majors'] vetting report. They have their tentacles everywhere which makes it impossible to avoid them.

Such extensive involvement of Oil Majors in vetting is believed to have helped the tanker sector achieve a better safety record than other sectors in shipping (Lloyds List, 2005; 2007). The managers in this study agreed and felt that although oil majors' safety initiatives were highly onerous they were at the same time beneficial. They were unanimous in agreeing that every measure taken for the purpose of passing SIRE inspections resulted in making their tankers safer. As one manager put it:

You would find a striking difference in the level of professionalism in our tanker officers when you compare them with those on the bulkies [ships trading solid cargo in bulk]. It is not a criticism of our bulk carrier staff, but we are able to raise the standard of the tankers simply because we can use Oil Majors' directive as the driving force.

While 'the driving force' led the managers to invest more resources, it was also capitalised on by managers to push ship staff to work harder. Managers were of the opinion that seafarers 
needed to be monitored and pressed because they would not make enough effort on their own. In this context, oil majors' inspection gave them a legitimate reason to push. In the interviews they were forthright in explaining how they had to push the seafarers to achieve this challenging task and as such were not apologetic in their ways of going about. One manager, for instance, said:

I have to push the seafarers to achieve our business. They need the kick in their backsides. Unless we [managers] apply this level of pressure we would never be able to realise the level of safety that we have managed on our fleet.

Apart from providing a legitimate reason, oil majors' inspection also gives guidelines to monitor and press for work on ships, as the SIRE inspection protocol lays down detailed and operational standards against which ship staff need to manage and maintain their ships. The managers used different coercive techniques, such as repeatedly sending harshly worded emails and making phone calls, to remind ship staff of their duties and urge them to work. One of the senior engineers articulated such communication in his interview:

The company [managers] keeps sending us threatening emails - they just get very active all on a sudden and send us lot of reminders - our own defect lists are sent back to us, typical concerns identified in oil majors' inspection generally and also a long list of defects that were reported by inspectors in other ships of our company... The bottom line is to convey "do what you have to, but pass the inspection".

On top of sending reminders, the managers also visited ships when they felt it was necessary. Ship visits bridged the distance between shore and ships, and allowed managers to directly monitor their offshore colleagues. One manager, for instance, mentioned: 
As soon as we fix an inspection we inform the ship. Then we remind them of all the defects and hot spots. We have to guide them and tell them exactly what to do. Sometimes we also need to visit the ship to convey the seriousness. In fact I've just returned from a ship in the States.

Seafarers construed these reminders and visits as pressures applied by the managers to pass inspection. A chief officer called these inspections as 'pressures from the managers on top of everyday pressures' that they were subjected to, and a captain summed it up as 'an additional pressure which only the seafarers were required to endure for the benefit of the whole company'. Furthermore, seafarers felt that their contribution did not receive adequate recognition and support from the managers although they carried out the actual preparation and had the ultimate responsibility to negotiate the inspection. In their view, they were 'ordered around' by managers which downplayed their professional ability and undermined their pride and dignity.

Despite the complaint, seafarers did their best to cope with the pressure. In the interviews all of them expressed a strong sense of fear of being blamed for poor inspection results. Being blamed would undermine not only their reputations but also promotional prospects and even future job opportunities which were in the hands of managers (for details see Bhattacharya, 2012a). Even though the senior seafarers from Western European countries in one company were permanent employees, they too worried of being made redundant and replaced by colleagues earning lower salaries from Eastern European countries. As they shouldered more responsibilities on ships, senior officers in particular appeared more wary of the results as they felt that they would be apportioned blame in the event of poor outcomes. One of the captains, for example, said: 
You have no idea what happens when the oil majors report too many observations. Up to five is okay but anymore or even a single major observation then they [managers] will send e-mails like 'despite our repeated instruction you are still not doing these, can you please explain why you are not doing things properly?' We are genuinely scared how they [managers] might react to a failed inspection. They could even sack me.

Even though it might be an unintended consequence, Oil Majors provide a reason as well as means for managers to harshly control the labour process on ships, and their initiative helps managers justify work intensification. This finding is in line with previous research focussing on labour control (Newsome et al. 2013; Pulignano 2002), which however is just one part of the story. To have a multi-dimensional picture of this supply chain initiative, it is important to examine the other two pairs of relationships in the triangle.

\section{Collusion between managers and seafarers}

Although seafarers complained about the additional pressure, they, especially those serving in the senior ranks, were also of the view that passing oil major inspection was a mark of their professionalism. They shared with managers the opinion that SIRE inspections contributed immensely to the safety of oil tankers. Some of them took for granted that it was their job to ensure that their ship was safe and trading profitably. In their views, passing oil majors' inspection was such an example. One Chief Engineer commented:

I would not like to be asked by the superintendent about why I need certain spare part or why there are so many deficiencies in the oil major inspections... I believe it is my job to ensure that my owner gets good value for money. 
It seemed that Oil Majors not only enabled managers to justify their coercive pressure, but also helped with 'manufacturing consent' over work intensification (Burawoy 1979).

However, passing tanker vetting was seldom straightforward. In the interviews, every senior and junior officer was honest in admitting falsifying ship's logbooks and documents to claim that their ship was maintained consistently and that proper actions were taken in the right order and at the right time. The following comment made by one junior officer revealed this issue:

Before arriving at this port the captain, the chief officer and I each spent around an extra six hours every day for a whole week filling in and signing forms, checking and cross checking them - all because we were expecting an oil major inspection... we were clearing paperwork backlogs basically.

This comment also revealed the issue of fatigue caused by long working hours which was commonly expressed on all four ships. To maintain ships to the standards required by Oil Majors entailed demanding physical work as well as paperwork. Some officers complained that in the week prior to an expected inspection, they had to work up to 20 hours a day. Because fatigue was a major risk factor affecting safety (Smith 2007), SIRE inspections indeed paid attention to seafarers' recorded working hours to ensure they were sufficiently rested. However, seafarers admitted freely that such records ironically were routinely falsified for the purpose of passing the inspections.

In their interviews the managers too were forthright in admitting their awareness and support of such 'adjustments' and in fact indicated how they too were engaged in counter-signing and 
filling in forms and log books retrospectively in preparation for oil majors' inspections. Such activities of course were maintained off the record and carried out typically through phone conversations and when managers visited the ships in preparation for upcoming inspections. One of the company managers pointed out:

We need to look at the paperwork as soon as we go on the ship. Most times I sit with the Chief Engineer and the Captain to ensure that the paperwork is up-to-date. Certain things [forms and documents] such as those requiring my signature as the DPA (Designated Person Ashore), or responses to defect reports, or updated experience matrix as per the TMSA (Tanker Management Self-Assessment), or updated feedback on internal audit non-compliance reports I fill in [prior to the inspections] as I am always on the ship which is to be vetted.

Cheating on inspections surely is not uncommon. Baglioni (2015) in her research of Senegalese export horticulture for example noted that exporters often cheated on compliance with EU standards by mixing produce from uncertified farms with those from certified ones.

In the case of this research, however, falsifying records does not necessarily serve seafarers' interests, especially the records of working hours. If oil major inspectors noted that seafarers did not have sufficient resting hours, they would request managers to solve the issue which would require the managers to provide extra manpower on the ship and thus reduce work intensification. However, it is not difficult to understand why seafarers falsified record that was designed to protect their own interests. Given their fear of being blamed as mentioned earlier, seafarers did not have many options but to do it in line with managers' expectation. Passing inspections thus depended not only on driving seafarers to work harder, but also on collusion between the seafarers and managers. 
Nevertheless, seafarers were not always passive pressure bearers who had to collude with managers, and there were occasions in which they leveraged supply chain pressure to their advantages, to which we turn next.

\section{Countering manager prerogative}

On all of the research voyages it was of interest to note a counter perspective. In the interviews some of the seafarers of junior ranks such as junior officers, bosun and pump man shared an interesting narrative about how on certain occasions they had a very different experience with oil major inspectors. They reported that sometimes they chose to divulge some of their ships defects to inspectors.

This practice, however, should not be misconstrued as a rebellious attitude of the individual seafarers who did not toe the corporate line. It is critical that the context in which such decisions were taken is well understood. These seafarers who reported adopting such a technique were junior yet key members of staff. The common narrative that they shared was to do with reporting of equipment that were inoperative due to lack of spare parts. These equipment were

critical to safety or pollution matters. Also, from the interviews it was clear that reporting of such defects to the inspector was not done with any malicious intention, i.e. the seafarers were not reporting to hurt the commercial interest of the company or for any personal gain, as one bosun put it:

I don't report something to get compensation or some personal benefit; this is good for the ship and if I report the job will be done and the ship will become safer. The last time I showed the inspector how one UTI tape (for measuring liquid level in the cargo tanks) 
was not that working effectively - all it needed was a new probe. One time I showed how the light in the paint locker was not gas tight.

As a consequence of placing these defects on oil majors' non-compliance/observation list, seafarers reported that managers responded promptly and that the equipment was repaired or the required spare parts were dispatched to the ship with no further delays. Such prompt response gave them some degree of encouragement. They felt that they had been successful in persuading the management to make a serious response to their concerns albeit in an indirect way.

It was also evident from the interview that when these seafarers took such a step, they did so only after they had made a report to the management first, but felt that the managers 'did not respond to the defect report and delayed on purpose.' The seafarers most commonly referred to 'delay on managers' part in sending spare parts' as the reason for them to take this unusual bold step as a mechanism to vent their frustration but with positive intent of making their workplace safer. Such views were captured in several interviews as the one below from a junior engineer:

The manager will always say get it done, get that done and make things safe, but we can't make spare parts. Sometimes the managers delay because it costs a lot of money. They say yes, we will get it done but they never get the spare parts - sometimes months go by. Then comes oil major inspection. We try to hide but sometimes it is not possible to hide and it is also not safe to hide. Then I report. One time I showed how the incinerator cut off switch was not of correct specification. Maybe it was expensive but 
without it the whole ship is unsafe. So I pointed it out to the Shell inspector. It was put in the defect list and the spare came in the next port.

A pump man [a rating with specialised role on tankers] on one of the ships was forthright in divulging in the interview how he took advantage of oil major inspections. He pointed out that managers were not always true to their words about doing everything to ensure a safe ship and was critical of the way in which the managers pushed them to pass inspections but were not prepared to offer the corresponding level of support to the ships. The pump man gave an example of a leaking pump in the pump room and explain how it flooded the bilge in the pump room which compromised the ship's safety and increased their workload. He continued to explain why and how he decided to use oil majors' inspection to get the problem addressed. He said:

This is third time for me on this ship. I know this ship very well. I reported this problem to the chief mate long time back. But when I came back this time the same problem was still there and now you see it is still the same. You run the pump it leaks. You need to change the gasket at the sea-chest (main inlet from the sea). This requires shore help and some extra fitters. But the managers want to go on like this till the dry dock. It is no good like this. So, last month I showed it to the BP inspector. I told him, this one leaking. It came on the report and now we are getting some help in the next port to get it done in ballast (light) condition.

Even four out of the total of 16 senior officers on the four ships also disclosed in the interviews how they have in their career at least once covertly divulged shipboard safety related concerns to the inspectors. They too shared similar views while justifying the reasons for disclosing such 
secrets to the inspectors and pointed to the managers' deliberate and purposeful denial of addressing serious safety concerns on board ships. The following interview of a captain exemplified this point. He said:

I have leaked information to oil major inspectors many times. Look, I'm not a traitor and did that only when the office [managers] did not care about what I said to them. They rarely listen to us and do not see our problems. So unless someone else tells them they don't do [anything]. It puts us [the ship] in trouble. But if it is noted in the Oil Majors' report, spares and technicians [to repair the defect] await us in the next port.

From the quotations above, it is clear that managers wanted to save money, tacitly expecting seafarers to make do with inadequate resources and hide defects from inspectors. On some occasions, seafarers acted in line with such expectations which served to defeat the purpose of oil major inspections, while on others, some of them chose to deliberately disclose problems to inspectors.

Disclosing of problems and having them sorted out indicate a form of structural power (Wright 2000; see also Selwyn 2011; 2012) that seafarers gained from the triangular relationships. By effectively directing the supply chain pressure on to managers, seafarers were able to safeguard their interest of improving workplace safety. Nevertheless, they employed this power covertly and only as a last resort as their ability to leverage supply chain pressure was constrained by managers' coercive power. They were concerned if their exploitation of this power led to inspection failures, or if it raised suspicion among managers, they were likely to be punished. 
In his study of Brazilian grape farms, Selwyn (2011) observed that workers' unions utilised supply chain leverage to pressurise farm employers to comply with customer stipulated standards and improve workplace health and safety. As such, farm workers transformed their structural power into strong associational power. In the shipping industry, while the International Transport Workers' Federation (ITF), a global maritime union association, has developed effective bargaining strategies with ship managers to raise labour standards globally, the isolation and mobility of ships nevertheless act as barriers for union organisations to support seafarers at the workplace level (Kahveci and Nichols 2006; Lillie 2006). In the interviews, while seafarers stated to be aware of the ITF, they did not see any relevance of unions on board their ships (see Bhattacharya, 2012b). Unable to consolidate their structural power into associational power, understandably, seafarers could only take chances to leverage the supply chain pressure individually and sporadically in the shadow of managers' coercive power.

\section{Concluding discussion}

Drawing on the insights from the research on customer orientated service work (Bélanger and Edwards 2013; Fuller and Smith 1991; Gamble 2007), this paper examined the client-supplier management-worker triangular relations and power dynamics related to OHS supply chain initiatives in the tanker shipping industry. The findings suggest that while the SIRE inspection mechanism contributes significantly to tanker safety, it also puts a huge amount of pressure on shipping companies. However, being in a relative powerful position, managers largely passed the pressure on to seafarers. Capitalising on the demanding requirements of Oil Majors, managers felt legitimate to increase monitoring of labour process on ships and to squeeze more effort out of seafarers. The reactions of seafarers were ambivalence: some believed it was their job to bear with the pressure, whereas the majority of them complained about it. Despite the 
large amount of resentment, seafarers often chose to collude with managers falsifying paperwork, such as working hour records, and hiding equipment and machinery defects during inspections. Occasionally, however, seafarers strategically and covertly utilised the leverage of oil majors' pressure against managers, forcing them to make necessary investments in workplace safety. Briefly they deployed their structural power to defend their interests, albeit with great caution.

This paper is also built upon two different strands of previous research, one on labour control (Newsome 2010; Newsome et al. 2013; Pulignano 2002) and the other on labour agency (Carswell and De Neve 2013; Coe and Hess 2013; Selwyn 2011; 2012), in supply chains. By taking a triangular approach, it presents a multi-dimensional picture to complement the two strands of research, revealing that supply chain pressure can serve to reinforce labour control while simultaneously enhancing workers' structural power. Nevertheless, in the context of this research, seafarers could not transform structural power into associational power, as the Brazilian grape farm workers did in Selwyn's research $(2011 ; 2012)$. As such, their capability to exercise this form of power was rather limited - constrained by managers' coercive power, they could only exploit it covertly and sporadically. In this context and in addition to the two strands of previous literature, the triangular approach serves to bring a third dimension of power dynamics involved in supply chains to the surface, that is, more often than not, seafarers colluded with managers instead.

Thus, seafarers alternated between colluding with managers which was the norm and making use of supply chain leverage which was more of an exception. Instead of being contradictory, this practice reflects that seafarers had different interests with various priorities. While both 
securing promotion/employment and having a safe workplace serve their interests, the former appeared to have a higher priority. As such, they acted in line with management expectations, with either consent or resentment, to undermine oil majors' safety initiatives most of the time. Only on occasions when they were discontented with managers' irresponsibility, did they exploit their structural power cautiously to defend their interests of having a safe workplace. In other words, they exercised their agency by strategically adjusting their action to deal with the pressure and to best safeguard their interests.

This paper also makes a contribution in another front. As the triangular approach helps capture the complexity of power dynamics in supply chains, it provides a context in which the impacts of supply chain initiatives can be evaluated in a more nuanced way. Previous research showed how the approach adopted by the lead firms, which apply market pressure, determine improvement or deterioration of labour standards and working conditions down the chain (Newsome et al. 2013; Wright and Kaine 2015). Among them some have criticised this approach as it undermined worker participation from the perspective of the industrial relations (see Bhattacharya and Tang, 2013) whereas some have also revealed that effective monitoring and penalty regimes help (positive) supply chain initiatives improve OHS outcomes (Walters et al. 2016; Walters and James 2011). While these findings provide valuable insight, they overlooked workers' responses. This paper adds to this body of literature by showing that workers' ability to exercise their structural power can make a difference. In Selwyn's research (2011) workers transformed structural power into associational power which served to improve OHS standards at workplace. In this research, by contrast, seafarers could not exploit their structural power collectively and effectively but chose to collude with managers which undermined the supply chain initiatives. 
It is worthwhile pointing out that seafarers are not a homogeneous group and they occupy different ranks in a strict hierarchy of shipboard social structure which often generate tensions and conflicts. However, the focus of this paper is on OHS and a safe workplace with adequate resources and manpower which is in the interest of all seafarers. Even though senior officers perform the function of shipboard management, they are different from shore-based management in that their priority is on their personal safety rather than corporate profit. In this respect, senior officer, junior officers and ratings are literally and metaphorically on the same boat. Therefore, this paper treats seafarers as one party in the triangle. Given tensions and conflicts are likely to exist on shipboard workplace itself, it would be interesting to further investigate how supply chain initiatives might affect these, but this is beyond the scope of this paper.

\section{Acknowledgements}

This paper is based on a study funded by the Nippon Foundation.

\section{References:}

Baglioni, E. (2015). Straddling contract and estate farming: accumulation strategies of Senegalese horticultural exporters. Journal of Agrarian Change, 15(1), 17-42.

Barrientos, S. (2008). Contract labour: The 'Achilles heel' of corporate codes in commercial value chains. Development and Change, 39(6), 977-990.

Barrientos, S.W. (2013). 'Labour chains': analysing the role of labour contractors in global production networks. The Journal of Development Studies, 49(8), 1058-1071. 
Beaumont P, Hunter L, Sinclair D (1996). Customer-supplier relations and the diffusion of employee relations changes. Employee Relations, 18(1): 9-19.

Bélanger, J. and Edwards, P. (2013). The nature of front-line service work: distinctive features and continuity in the employment relationship. Work, Employment \& Society, 27(3), 433-450.

Bezuidenhout, A., \& Buhlungu, S. (2011). From compounded to fragmented labour: mineworkers and the demise of compounds in South Africa. Antipode, 43(2), 237-263.

Bhattacharya, S. (2012a). The effectiveness of the ISM Code: A qualitative enquiry. Marine Policy, 36(2), 528-535.

Bhattacharya, S. (2012b). Sociological factors influencing the practice of incident reporting: the case of the shipping industry. Employee Relations, 34(1): 4-21.

Bhattacharya, S. and Tang, L. (2013). Fatigued for safety? Supply chain occupational health and safety initiatives in shipping. Economic and Industrial Democracy, 34(3), 382 - 398.

Burawoy, M. (1979). Manufacturing consent: Changes in the labor process under monopoly capitalism. Chicago: University of Chicago Press.

Carroll M, Vincent S, Hassard J, Cooke FL (2005). The strategic management of contracting in the private section. In: Marchington M, Grimshaw D, Rubery J, Willmott H (eds) Fragmenting Work: Blurring Organizational Boundaries and Disordering Hierarchies. Oxford: Oxford University Press, pp. 135-156.

Carswell, G., \& De Neve, G. (2013). Labouring for global markets: Conceptualising labour agency in global production networks. Geoforum, 44, 62-70.

Coe, N. M., \& Hess, M. (2013). Global production networks, labour and development. Geoforum, 44, 4-9. 
Deakin, S. and Koukiadaki, A. (2009). Governance processes, labour-management partnership and employee voice in the construction of Heathrow terminal 5. Industrial Law Journal, 38(4), 365-389.

Distelhorst, G., Hainmueller, J. and Locke, R.M. (2017). Does Lean Improve Labor Standards? Management and Social Performance in the Nike Supply Chain. Management Science, 63(3): 707-728.

Fuller L, Smith V (1991). Consumers' reports: management by customers in the service economy. Work, Employment and Society, 5(1): 1-16.

Gamble J (2007). The rhetoric of the consumer and customer control in China. Work, Employment and Society 21(1): 7-25.

Grimshaw D, Marchington M, Rubery J, Willmott H (2005) Conclusion: Redrawing boundaries, reflecting on practice and policy. In: Marchington M, Grimshaw D, Rubery J, Willmott H (eds) Fragmenting Work: Blurring Organizational Boundaries and Disordering Hierarchies. Oxford: Oxford University Press, pp. 261-307.

Hammer, N., and Plugor, R. (2016). Near-sourcing UK apparel: value chain restructuring, productivity and the informal economy. Industrial Relations Journal, 47(5-6), 402-416.

Howell, K. E., \& Bhattacharya, S. (2016). Functional and territorial jurisdictions: Regulating a globalized shipping industry. Journal of Transport Geography, 55, 92-100.

ILO (2001). The impact on seafarers' living and working conditions of changes in the structure of the shipping industry. http://www.ilo.org/global/publications/ilo-bookstore/orderonline/books/WCMS_PUBL_9221122379_EN/lang--en/index.htm

James, P., Walters, D., Sampson, H., and Wadsworth, E. (2015). Regulating the employment dynamics of domestic supply chains. Journal of Industrial Relations, 57(4), 526-543. 
Korczynski, M. (2013). The customer in the sociology of work: different ways of going beyond the management-worker dyad. Work, Employment and Society, 27(6), NP1-NP7.

Korczynski, M., Shire, K., Frenkel, S. and Tam, M. (2000). Service work in consumer capitalism: customers, control and contradictions. Work, Employment and Society, 14(4), 66987.

Lever, J. and Milbourne, P. (2017). The structural invisibility of outsiders: The role of migrant labour in the meat-processing industry. Sociology, 51(2): 306-322

Lloyd C, James S (2008). Too much pressure? Retailer power and occupational health and safety in the food processing industry. Work, Employment and Society, 22(4): 713-730.

Lloyds List. (2005). 'Why vetting improves the ISM Code', Lloyd's List, 28 April.

Lloyds List (2007). 'Equasis sets down state of world fleet', Lloyd's List, 08 January.

Locke, R.M., Rissing, B.A. and Pal, T. (2013). Complements or substitutes? Private codes, state regulation and the enforcement of labour standards in global supply chains. British Journal of Industrial Relations, 51(3), 519-552.

Marchington M, Vincent S (2004). Analysing the influence of institutional, organizational and interpersonal forces in shaping inter-organizational relations. Journal of Management Studies, 41(6): 1029-1056.

Mayhew C, Quinlan M (2006). Economic pressure, multi-tiered subcontracting and occupational health and safety in Australian long-haul trucking. Employee Relations, 28(3): 212-229.

Newsome, K. (2010). Work and employment in distribution and exchange: moments in the circuit of capital. Industrial Relations Journal, 41(3), 190-205. 
Newsome, K., Thompson, P. and Commander, J. (2013). 'You monitor performance at every hour': labour and the management of performance in the supermarket supply chain. New Technology, Work and Employment, 28(1), 1-15.

Pulignano, V. (2002). Dynamic forms of control at work: a research note on integrated supply chains in the motor industry in southern Italy. Work, Employment \& Society, 16(1), 185-196.

Rosenthal, P. (2004). Management control as an employee resource: The case of front-line service workers. Journal of Management Studies, 41(4), 601-622.

Sampson, H., \& Bloor, M. (2007). When Jack gets out of the box: the problems of regulating a global industry. Sociology, 41(3), 551-569.

Scarbrough H (2000). The HR implications of supply chain relationships. Human Resource Management Journal, 10(1): 5-17.

Selwyn, B. (2011). The political economy of class compromise: Trade unions, capital-labour relations and development in north east Brazil. Antipode, 43(4), 1305-1329.

Selwyn, B. (2012). Beyond firm-centrism: re-integrating labour and capitalism into global commodity chain analysis. Journal of Economic Geography, 12(1), 205-226.

Thompson, P. and Van den Broek, D. (2010). Managerial control and workplace regimes: an introduction. Work, Employment \& Society, 24(3), 1-12.

Walters, D. Quinlan, M. Johnstone, R. and Wadsworth, E. (2016). Representing miners in arrangements for health and safety in coalmines: A study of current practice. Economic and Industrial Democracy, December 01, 2016.

Walters D and James P (2011). What motives employers to establish preventive management arrangement? Safety Science, 49 (7): 988-994. 
Wright, C. F. (2016). Leveraging Reputational Risk: Sustainable Sourcing Campaigns for Improving Labour Standards in Production Networks. Journal of Business Ethics, 137(1), 195210.

Wright, C. F., and Brown, W. (2013). The effectiveness of socially sustainable sourcing mechanisms: Assessing the prospects of a new form of joint regulation. Industrial Relations Journal, 44(1), 20-37.

Wright, C. F., and Kaine, S. (2015). Supply chains, production networks and the employment relationship. Journal of Industrial Relations, 57(4), 483-501.

Wright, E. O. (2000). Working-class power, capitalist-class interests, and class compromise. American Journal of Sociology, 105(4), 957-1002. 